STRUCTURE AND SYNTHESIS OF SMALL

VIRUSES AND THEIR COMPONENT PARTS

\title{
Progress : Report
}

Paul Kaesberg

Biophysics Laboratory

University of Wisconsin

Madison, Wisconsin 53706

February 16, 1972 - February 16, 1973

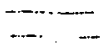

PREPARED FOR THE U. S. ATOMIC ENERGY COMMISSION UNDER CONTRACT NO. AT (11-1) - 1633

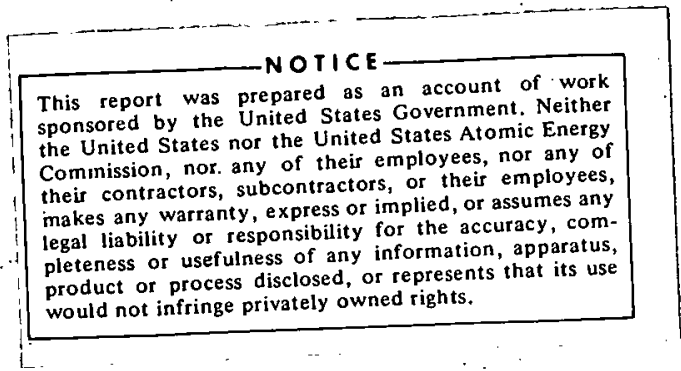




\section{DISCLAIMER}

This report was prepared as an account of work sponsored by an agency of the United States Government. Neither the United States Government nor any agency Thereof, nor any of their employees, makes any warranty, express or implied, or assumes any legal liability or responsibility for the accuracy, completeness, or usefulness of any information, apparatus, product, or process disclosed, or represents that its use would not infringe privately owned rights. Reference herein to any specific commercial product, process, or service by trade name, trademark, manufacturer, or otherwise does not necessarily constitute or imply its endorsement, recommendation, or favoring by the United States Government or any agency thereof. The views and opinions of authors expressed herein do not necessarily state or reflect those of the United States Government or any agency thereof. 


\section{DISCLAIMER}

Portions of this document may be illegible in electronic image products. Images are produced from the best available original document. 
PROGRESS REPORT

ABSTRACT

Most of the work during the period February 16, 1972 to February 16, 1973 involved translation of brome mosaic viral RNA in a cell-free system derived from wheat embryo.

The 4 RNA's of brome mosaic virus: were found to induce substantial incorporation of amino acids into protein when used as messengers in a cellfree protein synthesizing system derived from wheat embryo. RNA 4 is a highly efficient monocistronic messenger for the viral coat protein. Acetate, derived from acetyl coenzyme $A$, is incorporated into the in vitro product. Although RNA 3 also contains the coat protein cistron, it induces synthesis mostly of a protein larger than coat protein. RNA's 1 and 2 also induce the synthesis of substantial amounts of protein other than coat protein. However, an equimolar mixture of RNA's 3 and 4 or of $1,2,3$ and 4 induces synthesis of coat protein almost exclusively. This suggests that the coat protein cistron, when present as a monocistronic messenger, inhibits the translation of all other viral messages. 


\section{INTRODUCTION}

This report describes work done for the Atomic Energy Commission under Contract \# AT(11-1)-1633, in the laboratory of the principal investigator Professor Paul Kaesberg. During the period covered by this report the principal investigator devoted approximately 258 of his time to this project. He is expected to continue at this rate.

Part of the work done on this project resulted in publications and in accord with A.E.C. instructions, the information contained therein is not repeated here. Copies of these publications are enclosed:

coo-1633-25 Enzyme-mediated binding of tyrosine to brome mosaic virus ribonucleic acid. Hall, T. C., Shih, D. S., and Kaesberg, P. Biochem J. 129, 969. (1972).

C00-1633-26 Electrophoretic and other properties of bacteriophage $Q B$ : The effect of a variable number of read-through proteins. Radloff, Roger J. and Kaesberg, P. J. Virol. 11, 116 (1973).

The remainder of the work is reported below.

\section{SCIENTIFIC BACKGROUND}

Viruses have many features in common, but for a variety of technical and practical reasons, some properties are more readily studied in one virus, some in another. Over a period of years we have studied a small number of viruses, selected on the basis of their accessability to the elucidation of the important properties of viruses in general. Because viruses with multiple genomes are now of special interest to virologists we proposed last year to emphasize work with BMV, a small multiple component virus--the only one known whose nucleic acids are competent messengers in a cell-free protein syntheiszing system--moreover a eukaryotic system.

Although knowledge of viruses having multiple RNA components dates back to our reports of squash mosaic virus in 1955 and our work with alfalfa mosaic 
virus in 1958 , it was demonstrated only recently that such components have biological significance. Among the best documented are the cases for tobacco rattle virus, alfalfa mosaic virus, and most recently BMV (brome mosaic virus). All known multi-component viruses except BMV reveal themselves because their several virions have distinguishing sedimentation coefficients. However, the three virions of BMV sediment almost identically, and it is their isolated RNAs that distinguish them.

Viruses with multiple components are now of great interest to virologists because they exist in such medicaliy important viruses as influenza and tumor viruses. No bacterial viruses with multiple genomes are known, nor are they likely to be found because of the smallness of bacterial cells. One thus has to depend on plant viruses (and easily accessible animal viruses--if such exist) for studies of the characteristics of multiple genomes. BMV is an excellent virus with which to initiate such studies. It is easy to obtain, to handle and to do a variety of in vitro investigations.

The RNA isolated from BMV exhibits 3 components in the ultracentrifuge. corresponding to molecular weights-of approximately $1.0 \times 10^{6}, 0.7 \times 10^{6}$ and $0.3 \times 10^{6}$ daltons. With the advent of techniques for polyacrylamide gel electrophoresis of large RNAs, it was shown that the large component of RNA identified in centrifuge patterns consists, in fact, of two RNAs differing only slightly in molecular weight. Thus there exist 4 species of BMV RNA contained in 3 virions distinguished by their slightly different densities. Surprisingly, the 3 largest RNAs, collectively, are infectious. The smallest RNA makes no contribution to the infectivity, but is regenerated upon infection and appears in the progeny virus. It is therefore a strong inference that all three virions, acting in concert, comprise the infectious entity of the viral disease. Complementation studies have also shown that the gene for the BMV coat protein 
occurs in the $0.7 \times 106$ RNA component. Details of this work are described in the reports C00-1633-21 and C00-1633-22.

Even though BMV has important features that suggest its use as a test object for studying multicomponent viruses, it, along with all other plant viruses, had one major disadvantage: till very recently it has been exceedingly difficult to do in vitro protein synthesis experiments in systems derived from plants $(1,2)$.

Very recently, Klein, Nolan, Lazar and Clark (3) showed, quite unequivocally, that viral coat protein can be synthesized in a wheat embryo cell-free system programmed with the RNA of satellite tobacco necrosis. virus (STNV). The in vitro product has nearly the same spectrum of tryptic peptides as authentic STNV coat protein, although it is slightly lower in molecular weight, presumably as a consequence of an aberrant post-translational proteolytic cleavage. Klein et al presented evidence that translation is initiated correctly and that synthesis of the single product is substantial. The exceptional success of this in vitro synthesis is attributable to the careful definition, by these investigators and also by Marcus and his colleagues $(4,-5)$, of several of the important variables of the wheat system.

The efficacy of the wheat embryo system, the partial success of BMV RNA and STNV RNA translation in E. coli extracts $(6,7,8)$ and the fact that wheat is a natural host of BMV (although not of STNV) has prompted us to test the BMV RNA's as messengers in a wheat embryo system. We found that the BMV RNA's serve as excellent messengers--with an efficiency comparable to that reported for bacteriophage RNA in E: coli extracts.

During the past year we have studied the BMV-wheat embryo system in some detail as is described below. 
RESULTS

Stimulation of amino acid incorporation by BMV RNA.

Addition of BMV RNA to wheat embryo cell-free, extracts leads to substantial stimulation of amino acid incorporation. Table I shows the occurrence of approximately a 50-fold greater incorporation of $\left[{ }^{14} \mathrm{C}\right]$-leucine in the presence of unfractionated BMV RNA than in its absence. Similar levels of incorporations occur when RNA 4,3 or a mixture of $1+2$ are present. Thus, the two smaller RNA components and one or both of the two larger components are active messengers. Under the conditions of Table I the quantity of RNA used is above the minimum saturation level. When less than saturating amounts of RNA were used, leucine incorporations of 127 and 204 p moles per $\mu$ g of RNA were obtained for RNA's 3 and 4 , respectively at the leucine saturating level: For RNA 4 this corresponds to synthesis of approximately 4 molecules of BMV protein per molecule of messenger RNA. Although quantitative comparisons are difficult to make, we believe this efficiency of incorporation equals or exceeds that induced by any other viral messenger: The incorporation is greater than that obtained under somewhat. different conditions, for a cell-free system from E. coli programmed with phage $Q B$ RNA as reported in the literature (8), and is about the same as obtained by us under closely. comparable conditions. It is about 10-fold greater than that obtained when the wheat embryo system is programmed with STNV RNA, presumably, reflecting the status of BMV RNA as a homologous RNA.

The BMV RNA directed amino acid incorporation is markedly sensitive to Mg+t ion concentration. When $\mathrm{Mg}++$ is added as magnesium acetate the optimum is $3.6 \mathrm{mM}$. In common with other eukaryotic systems, the incorporation is inhibited by cycloheximide. Under the conditions of Table I, cycloheximide $(100 \mu \mathrm{g} / \mathrm{ml})$ reduces the incorporation to $0.2 \%$ of that in its absence. The incorporation level is unaffected by $50 \mu \mathrm{g} / \mathrm{ml}$ chloramphenicol. 
In vitro translation of $\underline{\text { RNA }} \underline{4}$.

The in vitro synthesized products directed by the BMV RNA's.were analyzed on SDS-polyacrylamide gels. Figure 1 shows the gel electrophoretic pattern of the $\left[{ }^{3} \mathrm{H}\right]-$ labelled in vitro product directed by RNA component 4 . Most of the $3_{\mathrm{H}}$ label appears in a major component which coelectrophoreses with authentic BMV coat protein $\left(\left[{ }^{14} \mathrm{C}\right]-1\right.$ abelled).

As further identification, cyanogen bromide and tryptic peptide maps were made. $\left[{ }^{14} \mathrm{C}\right]-\mathrm{BMV}$ coat protein was mixed with $\left[{ }^{3} \mathrm{H}\right]$-labelled in vitro product and electrophoresed as above. Labelled proteins were eluted from the gels and treated with cyanogen bromide or trypsin. The electrophoretic patterns of peptides resulting from cyanogen bromide cleavage are shown in Figure 2 . The $\left[{ }^{14} \mathrm{C}\right]-$ and $\left[{ }^{3} \mathrm{H}\right]-$ labelled peptides coincide even in the positions of the minor bands which presumably correspond to cleavage of the polypeptide chain at amino acid residues other than methionine. Figure 3 shows the tryptic peptide patterns. The patterns of in vitro and authentic protein show substantial:similarity in positions of peaks of radioactivity although the ratios of $\left[{ }^{14} \mathrm{C}\right.$ ] to [ ${ }^{3} \mathrm{H}$ ] among some of the corresponding fractions are different. These differences should be expected because, of necessity, we used a mixture of [ $\left.{ }^{3} \mathrm{H}\right]$ amino acids of varied specific radioactivity. We have delayed detailed characterization of the polypeptides resulting from these cleavages until we have information concerning the primary structure of BMV coat protein. This is under active investigation in several laboratories. Nevertheless, comparison of the fractionation patterns of the in vitro and the authentic protein clearly leads to the conclusion that they must be nearly identical.

In order to establish whether the in vitro synthesized and the authentic protein are precisely the same, it would be necessary to determine the amino acid sequence of each. The most likely difference would be at the N-terminus. 
The N-terminus of BMV coat protein is known to be blocked although the blocking group has not been identified: By analogy with almost all known plant viruses, and in particular by analogy with cowpea chlorotic mottle virus, which is serologically related to BMV, the blocking group is almost certainly acetate. To test whether the in vitro product accepts acetate, $\left[{ }^{3} \mathrm{H}\right]$-acetyl coenzyme $A$ was incubated along with $\left[{ }^{14} \mathrm{C}\right]$-amino acids in the cell-free system. Gel patterns of the incorporation product (Figure 4) indicate that the radioactively labelled acetate is incorporated into the putative BMV coat protein. The ratio of [ $\left.{ }^{\mathrm{H}}\right]$ to $\left[{ }^{14} \mathrm{C}\right]$ radioacitvity of the coat protein peak of Figure 5 represents 1 acety 1 group per 11 leucine residues, which corresponds closely to one acetyl group per protein. Experiments with the initiation inhibitor aurintricarboxylic acid (ATA) indicate that the acetylation reaction is not involved in the initiation of protein synthesis. In those experiments ATA was added to the protein synthesis reaction mixture fifteen minutes after, and $\left[3_{\mathrm{H}}\right]$-acetyl CoA eighteen minutes after commencing incubation. The final concentration of ATA in the reaction mixture was $5 \times 10^{-5} \mathrm{M}$, at which level, no amino acid incorporation can be observed if the inhibitor is added prior to the starting of incubation. Polyacrylamide gel analysis showed that acetylation of coat protein was almost as great (918) as that of the control sample not treated with ATA. This result suggests that the acetylation reaction is a post-initiational modification of: the synthesized peptide.

Translation of RNA $\underline{3}$.

The in vitro results, above, show that RNA 4 contains the coat protein cistron. It is already known from complementation studies (9) that RNA 3 also contains the coat protein cistron. However, we find that the coat protein region is translated only to a very small extent from RNA 3. The principal product is a protein substantially larger than coat protein (designated protein 
3a). Figure 5á shows the pertinent electrophoretic pattern. In addition to protein $3 a$, there is a small band corresponding to coat protein as well as another minor band and heterogenous fast. moving materials which may be degraded or unfinished protein $3 a$ and coat protein. Tryptic analyses of protein 3a show that it has no tryptic peptides in common with coat protein tryptic peptides. If the protein $3 a$ and coat protein cistrons overlap, their reading frames are, of necessity, out of phase. Furthermore, experiments involving radioactively labelled acetyl coenzyme $A$ show clearly that protein $3 a$ does not accept acetate as does coat protein.

The data of Figure 5a suggests that the structure of BMV RNA component 3 is such that the cistron of protein $3 a$ is translated to a greater extent than that of BMV coat protein. However, if the wheat embryo system is presented with a mixture of RNA's 3 and 4 , the coat protein cistron (presumably on RNA 4) is translated preferentially. Figure $5 \mathrm{~b}, \mathrm{c}$ and $\mathrm{d}$ show the electrophoretic patterns of the in vitro products synthesized under the direction of various mixtures of RNA's 3 and 4. As shown in Figure 5d, when the two RNA components are presented in a one to one ration, the predominant product is coat protein. We infer that the tertiary structure of the cistronic region of coat protein is different on RNA's 3 and 4 . The structures are such that on RNA 4 the coat protein cistron is read at higher efficiency than cistron $3 a$ and on RNA 3 it is read at lower efficiency. Presumably, this reflects the relative accessibility of their ribosome binding sites with a resulting selective translation of the more accessible cistrons and the inhibition of translation of the less available cistrons.

Translation of $\underline{\text { RNA's }} \underline{1}$ and $2 \underline{2}$ and of unfractionated $\underline{\text { BMV }} \underline{\text { RNA. }}$

Because of difficulty of obtaining RNA's 1 and 2 in pure form and because there is little genetic and biological data concerning their cistronic content 
most of our in vitro studies involving them were done with their mixture. Although they catalyze the incorporation of substantial amounts of amino acid in the wheat embryo system, no single homogenous product predominates. Figure 6 shows that the products include several partially resolved bands as well as incorporation into heterogenous products dispersed throughout the analyzing polyacrylamide gels. However, when an equimolar mixture of all 4 BMV RNA's, or the original, unfractionated BMV RNA at high concentration, is used as a messenger, the product is mostly coat protein (Figure 7). Clearly, the presence of the coat protein cistron, in monocistronic form, inhibits the expression of all the other BMV RNA messages. When much lower quantities of the mixture are used, some translation of the cistrons of RNA's 1, 2 and 3 is evident, indicating that the inhibition of their translation results from competition by the coat protein cistron.

\section{SIGNIFICANCE OF THESE RESULTS}

The BMV RNA-wheat embryo combination has several properties that recommend its use for the study of eukaryotic protein synthesis in vitro: The synthesis is faithful and is large in amount. The protein products can be readily obtained in $\mu g$ quantities. Both monocistronic and polycistronic messages are available in large amount. One of the cistrons is available in two forms whose capacities for inducing synthesis differ greatly. Of the several proteins synthesized, at least one is acetylated. The extent of translation of the cistrons can be regulated by the addition of another cistron.

The most obvious implication already emerging from the in vitro studies of the BMV RNA-wheat embryo system relates to regulation of in vivo synthesis of the BMV viral proteins. Presumably, at an early stage of infection, proteins other than coat must bë synthesized--among them an RNA replicase. Later, coat 
protein must be made in great abundance. We may hypothesize, that, at first, the concentrations of the BMV RNA's provided by the infecting virions are such that all cistrons are read. At a later stage (after replication. of RNA has begun) some RNA 3 is enzymatically cleaved to yield substantial amounts of RNA 4. And it is this pre-translational cleavage that triggers the onset of abundant synthesis of coat protein and a decreased synthesis of all other proteins.

The multiplicity of functions. of RNA 4 is surprising considering that it is not required for infectivity. In addition to its role as coat protein messenger and its possible participation in regulating the translation of other cistrons, it is a structural component of the BMV virion which also contains RNA 3. Since virions containing RNA 3, alone, have not been observed, RNA 4, presumably, provides an important feature of virion conștruction. Also, in common with the other BMV RNA's, RNA 4, has a 3 ! terminal primary and secondary structure capable of accepting tyrosine in a tRNA charging system (10). The significance of this feature is obscure, although our own (unpublished) studies show that BMV RNA, modified so that it no longer is chargeable, is fully capable of serving as an in vitro messenger.

The small size of RNA 4 makes study of the functional significance of its sequence feasible and interesting. The RNA is only about 930 bases long and roughly 500 of these are consumed by the coat protein cistron. We assume there exists an untranslated region of the RNA between the 5' terminus and the coat protein region that serves as a ribosome binding site. There must also exist a region about the $3^{\prime}$ terminus that has a tRNA-like sequence. Furthermore, there must be sequences which enable binding of the RNA to BMV coat protein for the purpose of virion assembly and there may be sequences which facilitate initiation of replication of the RNA by a putative BMV RNA synthetase.

Finally, we should briefly mention other unanswered questions relating to 
BMV as a self-duplicating biological system. All 4 BMV RNA's contain information and all contribute to the survival of the virus. What are the functions of the RNA's 1 and 2 (and 3 ) and what are the advantages of having the genetic material divided among several particles? Why include RNA 4 in a virion even though that RNA is not needed for infectivity? What is the significance of the tRNA-like structure of the RNA's? In succeeding years of this work we expect to address ourselves to these questions.

This work was supported by the Biological Division of the Atomic Energy Commission. 
TABLE I

STIMULATION OF $\left[{ }^{14} \mathrm{C}\right]$-LEUCINE INCORPORATION BY BMV RNA

$\underline{\text { RNA ADDED }}$

(... $\quad \therefore \quad \therefore \cdots$

None

Unfractionated BMV RNA (68 $\mu \mathrm{g})$

RNA $1+2(10 \mu g)$

RNA $3(17.5 \mu g)$

RNA $4(10 \mu g)$ $\underline{\text { [14C] -LEUCINE INCORPORATION }}$

CPM

p Mole

$\begin{array}{rr}6,424 & 9.7 \\ 349,942 & 530 \\ 351,032 & 532 \\ 389,081 & 590 \\ 412,988 & 626\end{array}$

The reaction mixture contained $1 \mu \mathrm{Ci}$ of $[14 \mathrm{C}]$-leucine (specific activity $412 \mathrm{mCi} / \mathrm{m} \mathrm{mol}$ ) and was incubated for 60 minutes. Hot TCA insoluble. materials were recovered on Millipore filters. The filters were washed two times with 5\% TCA, dried and counted in a Beckman counter with $10 \mathrm{mls}$ of a scintillation fluid (composed of $4 \mathrm{~g}$ of 2, 5-Diphenyloxazole, $0.1 \mathrm{~g}$ of p-bis[2-(5-phenyloxazoly 1)] -benzene and $100 \mathrm{ml}$ of Biosolv (Beckman) per $900 \mathrm{ml}$ of toluene at an, efficiency of $86 \%$. 


\section{Figures.}

Figure 1. Coelectrophoresis of $[14 \mathrm{C}]-1$ abelled authentic coat protein with [3H]-1abelled in vitro synthesized products. In vitro protein synthesis was performed. The reaction mixture contained $5 \mu \mathrm{g}$ of RNA $4,5 \mu \mathrm{Ci}$ of $\left[{ }^{3} \mathrm{H}\right]$-labelled reconstituted protein hydrolyzate (algal profile), $0.5 \mu \mathrm{Ci}$ of $\left[{ }^{3} \mathrm{H}\right]$-methionine $(0.7 \mathrm{Ci} / \mathrm{mmol})$ and $0.01 \mu \mathrm{mol}$ each of asparagine; cysteine, glutamine and tryptophan. Incubation was for 30 minutes. A $200 \mu 1$ sample was mixed with about $32,000 \mathrm{cpm}$ of $\left[{ }^{14} \mathrm{C}\right]$-labelled authentic BMV coat protein and was subjected to electrophoresis. The gel was fractionated and each fraction counted in a Packard scintillation counter with $0.6 \mathrm{ml}$ of $\mathrm{H}_{2} \mathrm{O}$ and $5 \mathrm{mls}$ of a tT21 scinti11ation fluid (18) at an efficiency of $58 \%$ for $[14 \mathrm{C}]$ and $25 \%$ for $[3 \mathrm{H}]$. Electrophoresis was from left to right. [14C]-radioactivity, thin line; [3H]-radioactivity, bold line.

Figure 2. Comparison of peptides resulting from cyanogen bromide cleavage of $\left[{ }^{3} \mathrm{H}\right]$-labelled in vitro synthesized product and from $\left[{ }^{14} \mathrm{C}\right]-1$ abelled authentic coat protein. Protein synthesis was performed as described in Figure 1, except $8 \mu \mathrm{g}$ of RNA 4 was used. $\left[{ }^{3} \mathrm{H}\right]$-labelled protein isolated from three identical gels was mixed with about $32,000 \mathrm{cpm}$ of $\left[{ }^{14} \mathrm{C}\right]$-labelled coat protein and treated with cyanogen bromide. The resulting peptides were subjected to electrophoresis. The gel was fractionated and each fraction counted in $0.6 \mathrm{ml}$ of water and $5 \mathrm{ml}$ of tT21. $\left[{ }^{14} \mathrm{C}\right]$-radioactivity, thin line; $\left[{ }^{3} \mathrm{H}\right]$-radioactivity, bold line.

Figure 3. Chromatographic separation profiles of tryptic peptides from $\left[{ }^{3} \mathrm{H}\right]$ labelled in vitro synthesized protein and from $\left[{ }^{14} \mathrm{C}\right]$-labelled BMV coat protein. In vitro protein synthesis was as described in Figure 2. About $160,000 \mathrm{cpm}$ of 
[14C]-1abelled BMV coat protein was added to the incorporation mixture after incubation. Labelled proteins isolated from six identical gels were digested with trypsin and the resulting peptides were chromatographed on a Dowex 50X-8 column. Each fraction from the column was dried under vacuum, dissolved in $0.6 \mathrm{ml}$ of water and counted with $5 \mathrm{mi}$ of $t T 21$. The $[3 \mathrm{H}]$-profile was corrected for $\left[{ }^{14} \mathrm{C}\right]$ spillover $(11 \%$ of $[14 \mathrm{C}]$ counts). [14C] radioactivity, thin dashed line; [3H] radioactivity, bold line.

Figure 4. Incorporation of $\left[{ }^{3} \mathrm{H}\right]$ acetyl group into the in vitro synthesized coat protein. Protein synthesis conditions were as described in Figure 1, except $5 \mu \mathrm{Ci}$ of $[3 \mathrm{H}]$-acetyl coenzyme $\mathrm{A}$ was included in the reaction mixture and 0.5 $\mu \mathrm{Ci}$ of $\left[{ }^{14} \mathrm{C}\right]$-leucine was used instead of a $\left[{ }^{3} \mathrm{H}\right]$-amino acid mixture. [14 $\left.\mathrm{C}\right]$ radioactivity, thin dashed line; $\left[{ }^{3} \mathrm{H}\right]$ radioactivity, bold line.

Figure 5. Gel electrophoretic patterns of proteins synthesized under the direction of RNA 3 and of mixtures of RNA 3 and RNA 4. Protein synthesis was performed as described in Table 1. The reaction mixtures contained (a) $30 \mu \mathrm{g}$ RNA 3 (40 p mo1), (b) $20 \mu \mathrm{g}$ RNA 3 (26.7 p mo1), and $2 \mu \mathrm{g}$ RNA 4 (7.1 p mo1), (c) $15 \mu \mathrm{g}$ RNA 3 (20 p mo1) and $3 \mu \mathrm{g}$ RNA 4 (10.7 p mol) and, (d) $10 \mu \mathrm{gRNA} 3$ (13.3 p mol) and $4 \mu \mathrm{g}$ RNA 4 (14.2 $\mathrm{p}$ mol). The reaction mixtures were incubated for 60 minutes.

Figure 6. Gel electrophoretic pattern of proteins synthesized under the direction of a mixture of RNA 1 and RNA 2. Protein synthesis was performed as described in Table 1. Ten $\mu$ gof a mixture of RNA $1+2$ was used. 
Figure 7. Gel electrophoretic pattern of proteins synthesized under the dircetion of unfractionated BIN RWA. Protein synthesis was performed as described under Table 1. Sixty ug of the unfractionated BMV RNA was used. 


\section{REFERENCES}

1. See, for example, the review: Lucas-Lenard, J., and Lipmann, F., (1971)

Ann. Rev. Biochem. 40, 409-448.

2. See, for example, the review: Boulter, D. (1970) Ann. Rev. Plant Physiol. 21, 91-114.

3. Klein, W. H., Nolan, C., Lazar, J. M. and Clark, J. M., Jr. (1972) Biochemistry 11; 2009-2014.

4. Marcus, A., Luginbi11, B. and Feeley, J. (1968) Proc. Nat. Acd. Sci. U.S.A. $59,1243-1250$.

5. Marcus, A. (1970) J. Biol. Chem. 245, 962-966.

6. Stubbs, J. D. and Kaesberg, P. (1967) Virology 33, 385-397.

7. Clark, J. M., Jr., Chang, A. Y., Spiegelman, S. and Reichmann, M. E. (1965) Proc. Nat. Acd. Sci. U.S.A. 54, 1193-1197.

8. Rice, R. and Fraenke1-Conrat, H. (1973) Biochemistry 12, 181-187:

9. Lane, L. C. and Kaesberg, P. (1971) Nature New Bio1. 232, 40-43.

10. Hal1, T. C., Shih, D. S. and Kaesberg, P. (1972) Biochem. J. 129, 969-978. 


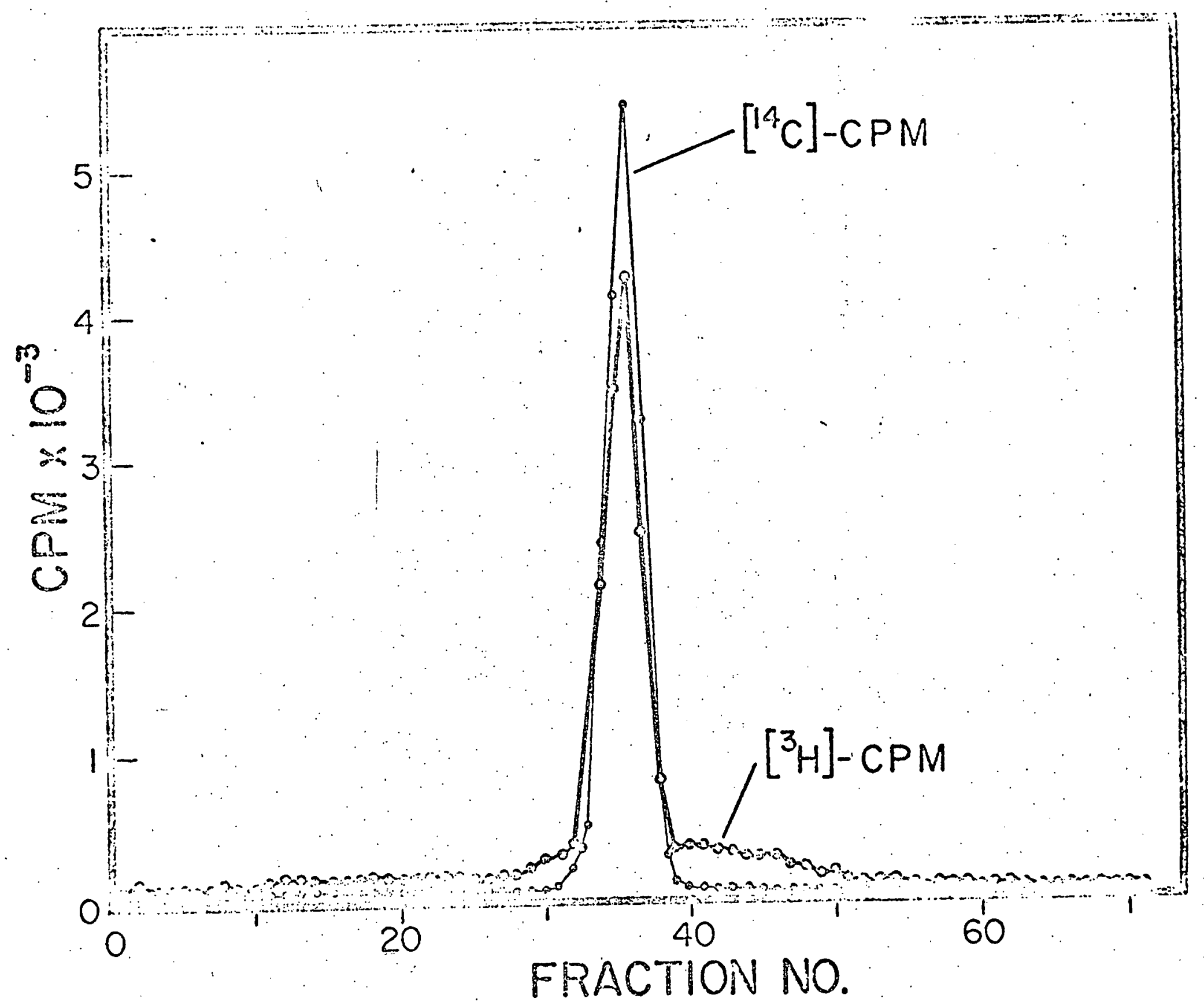




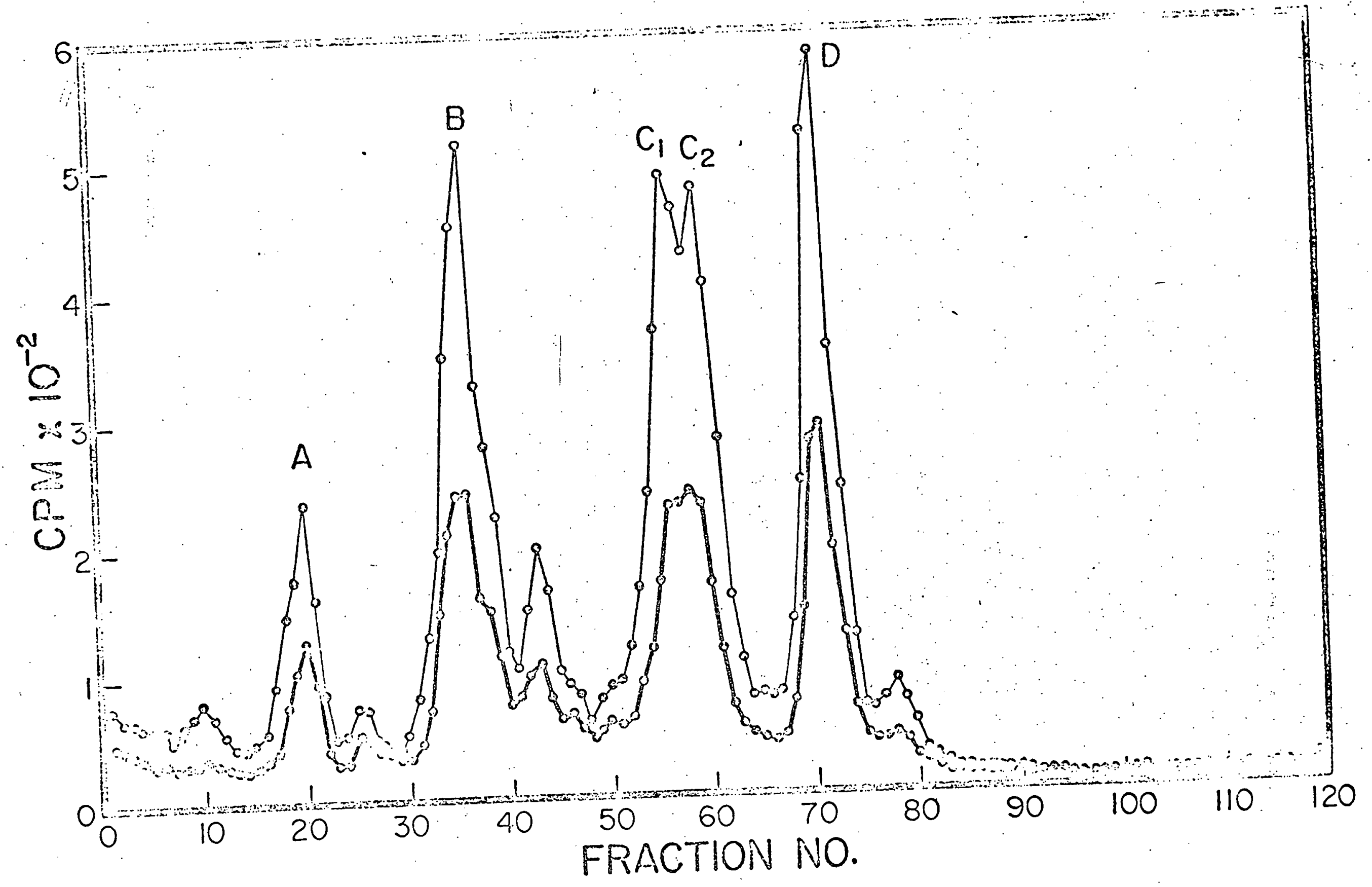




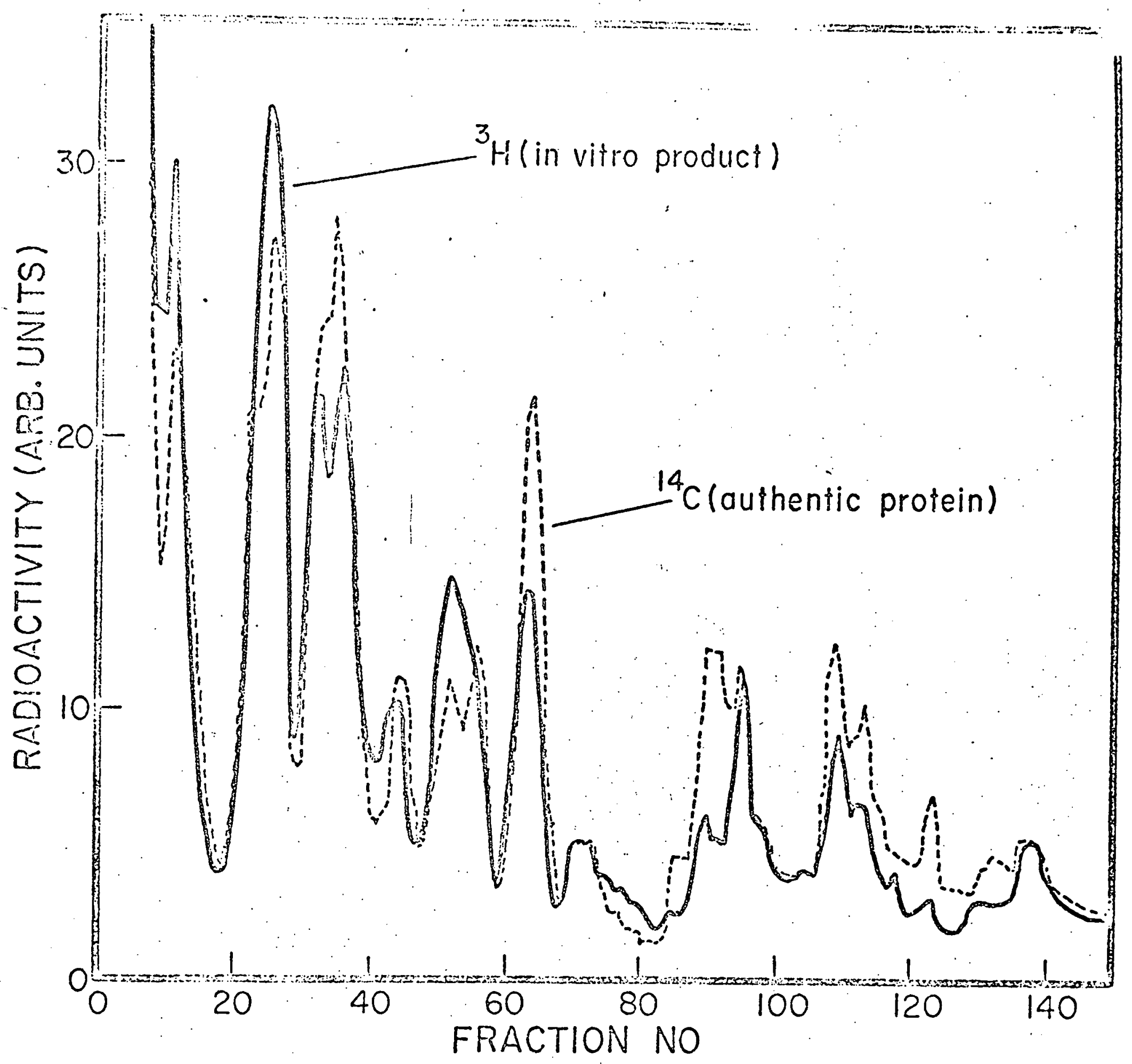




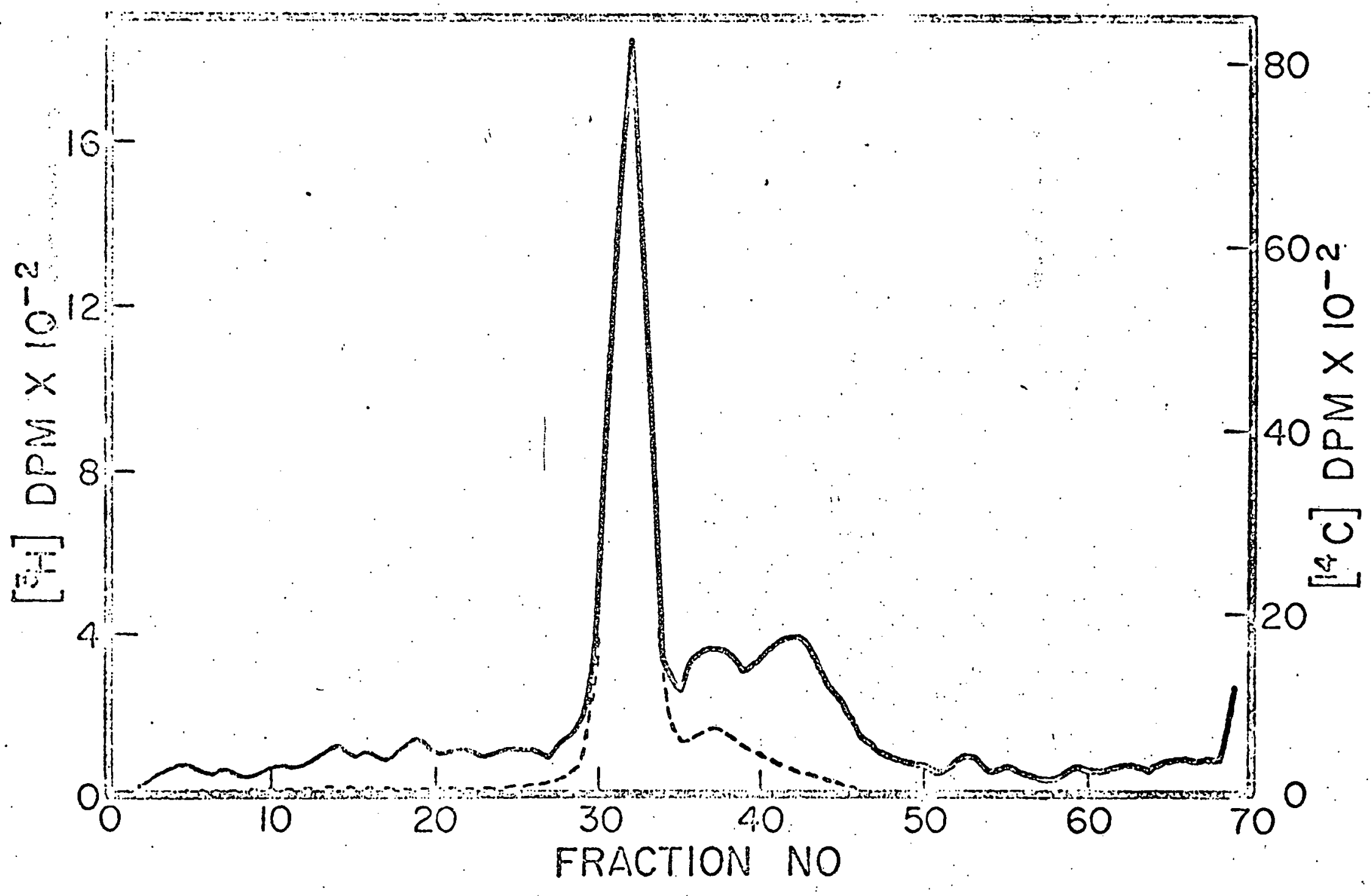




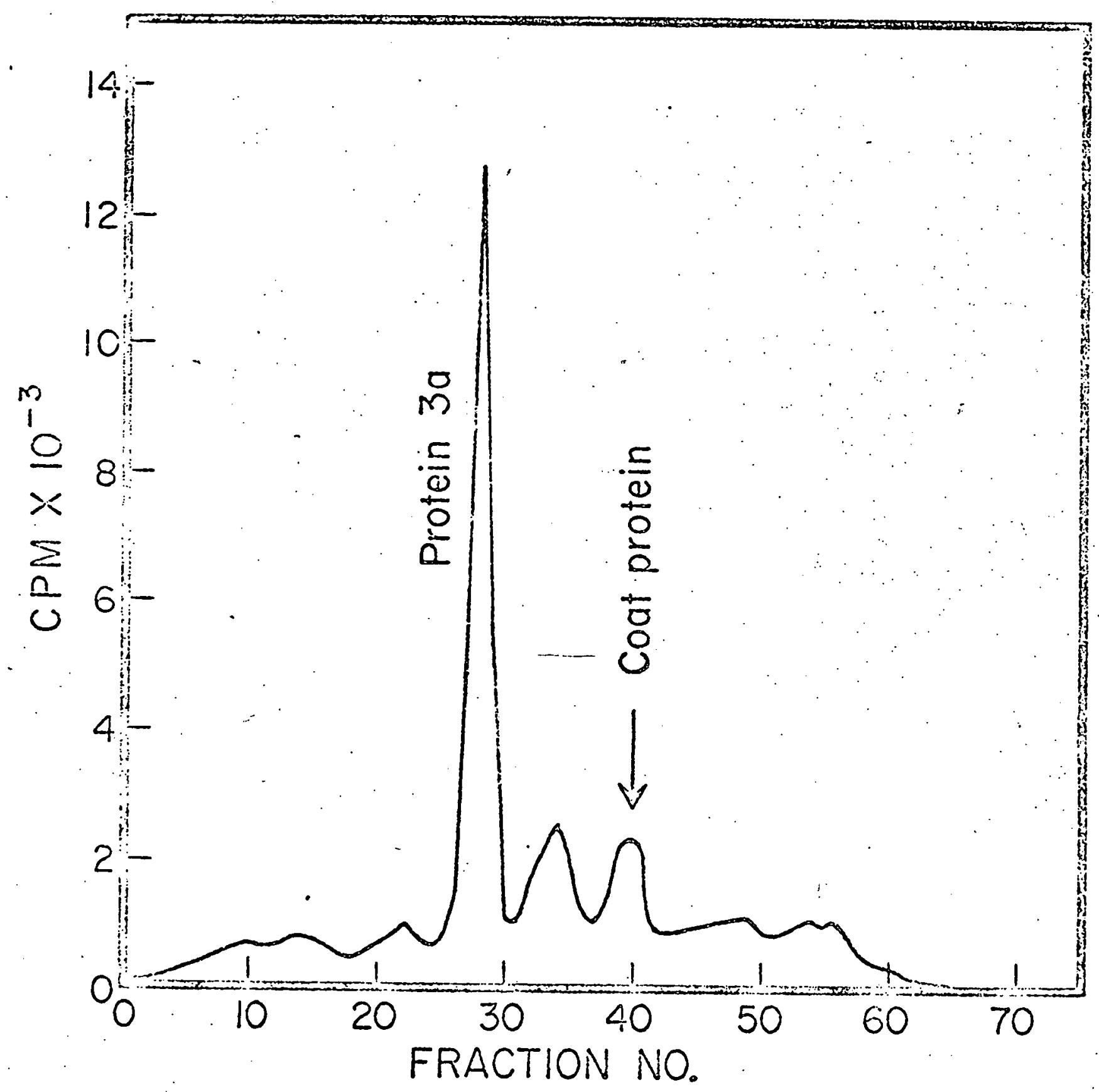




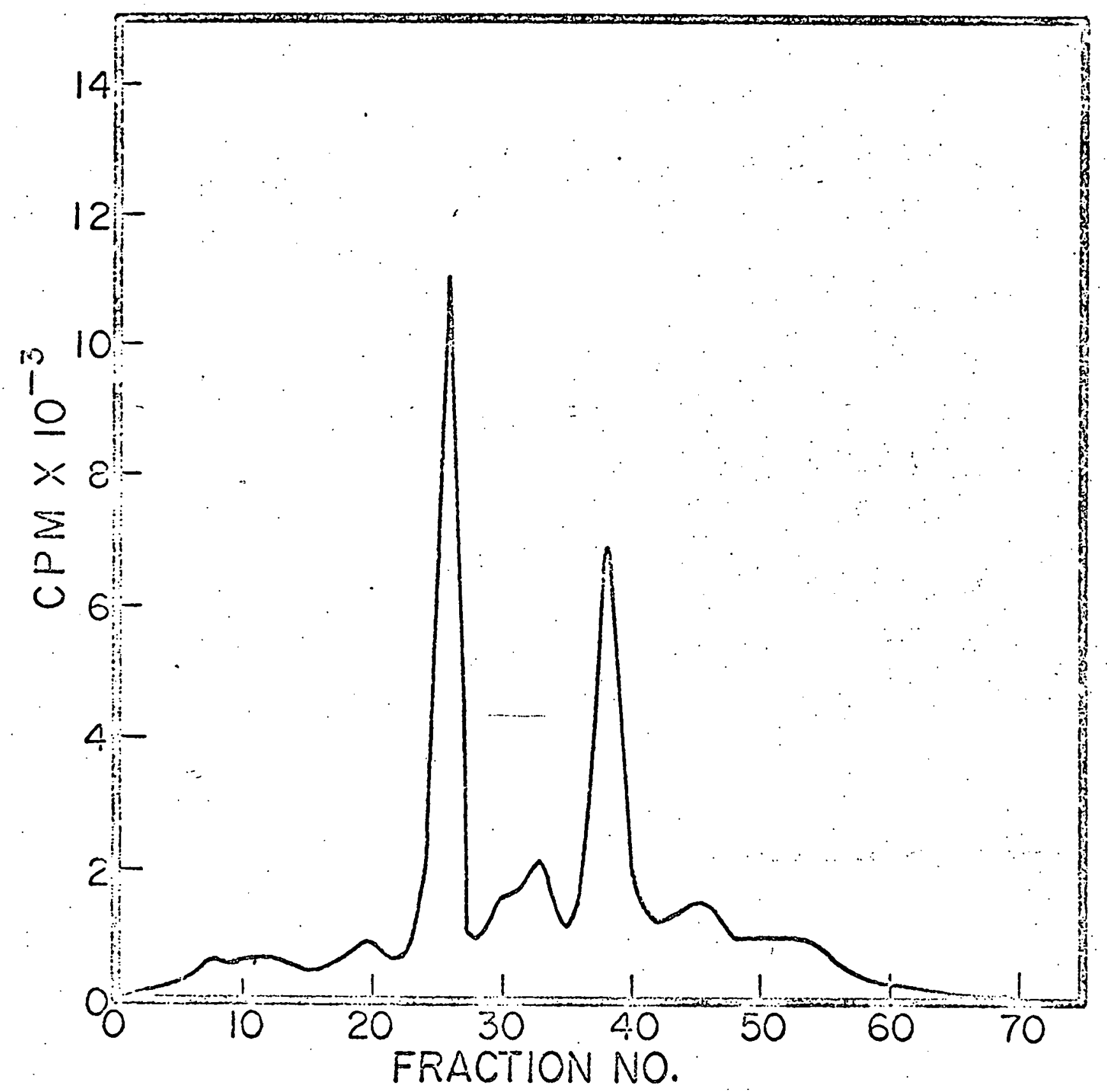




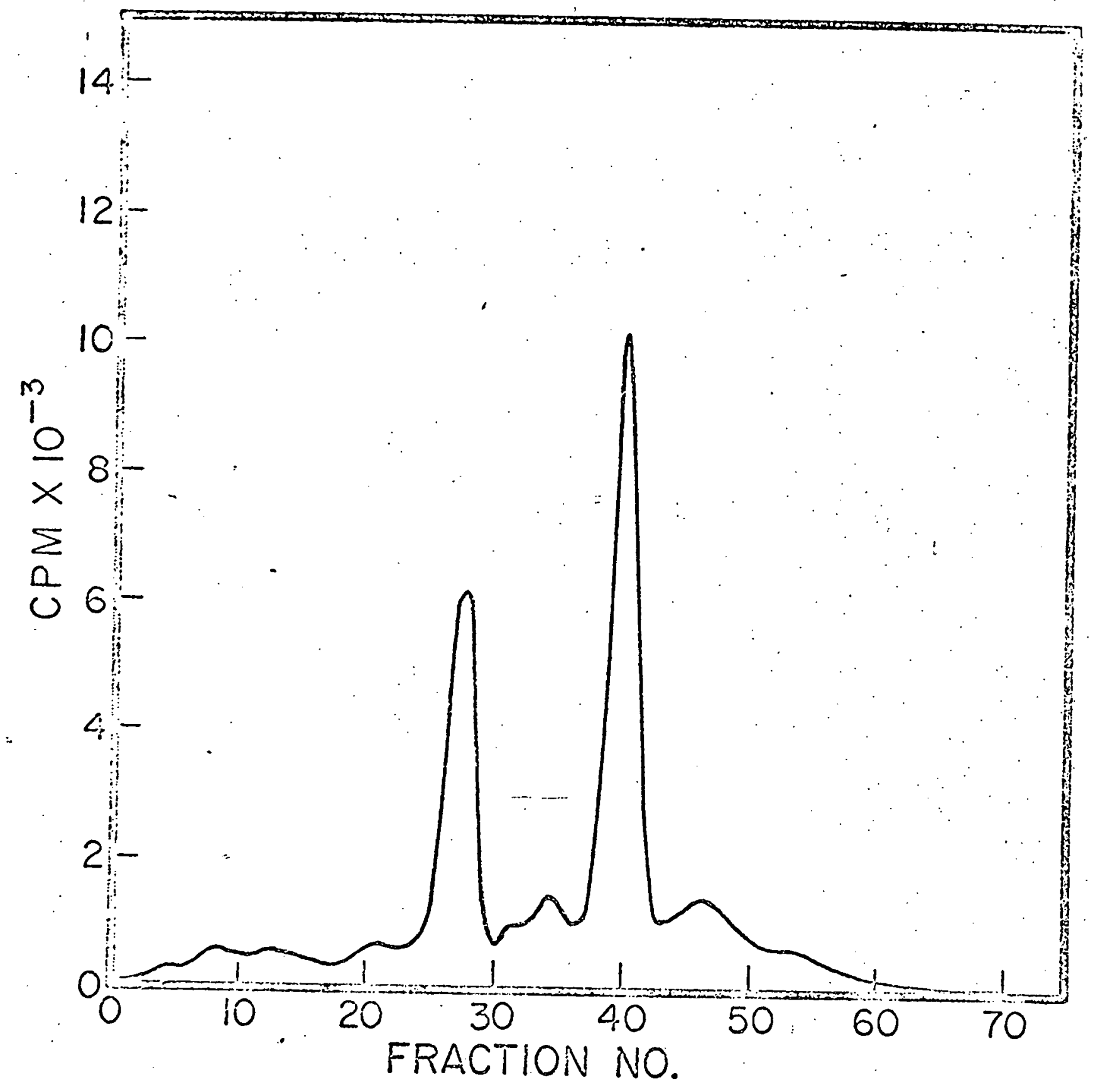




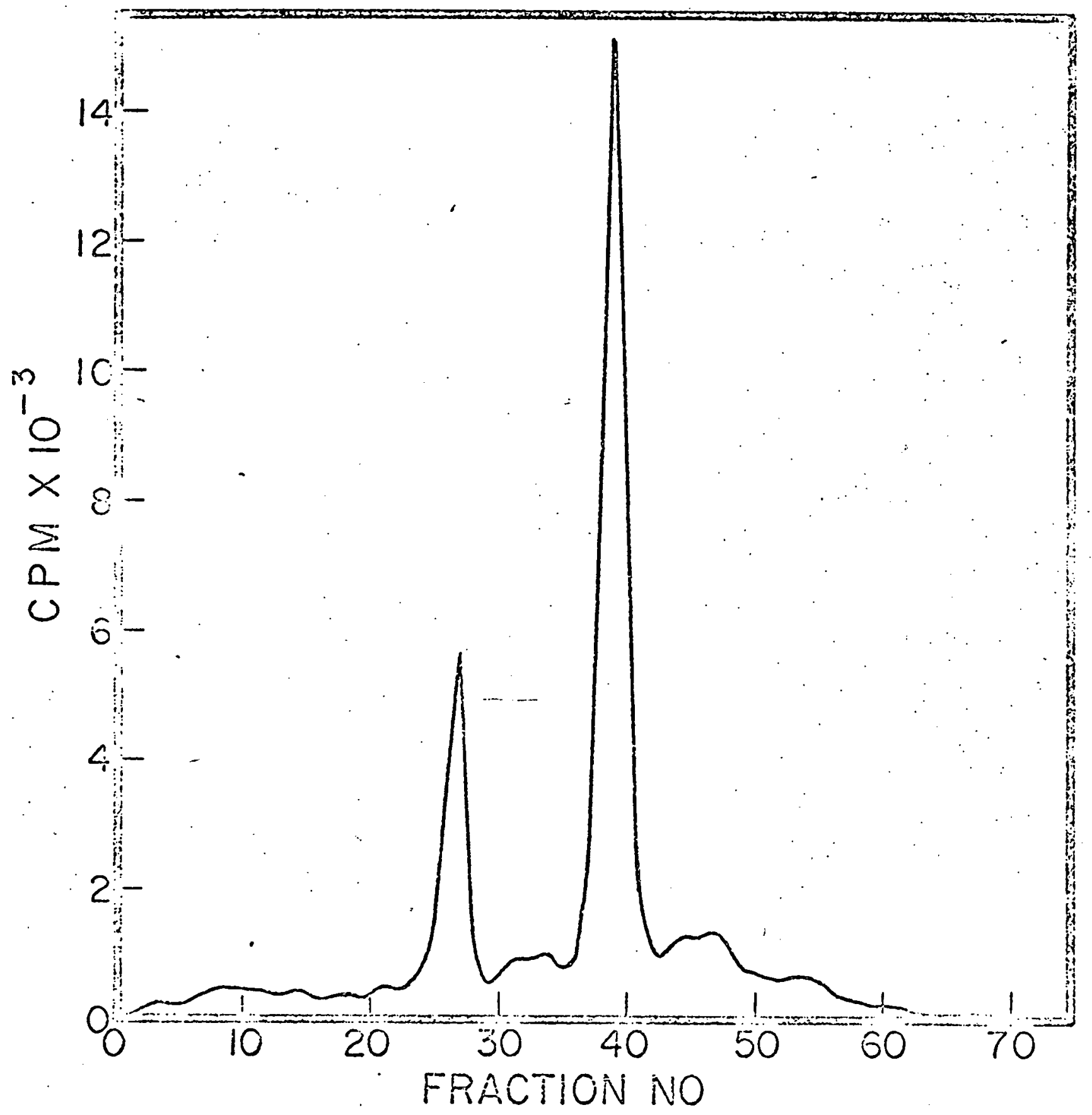




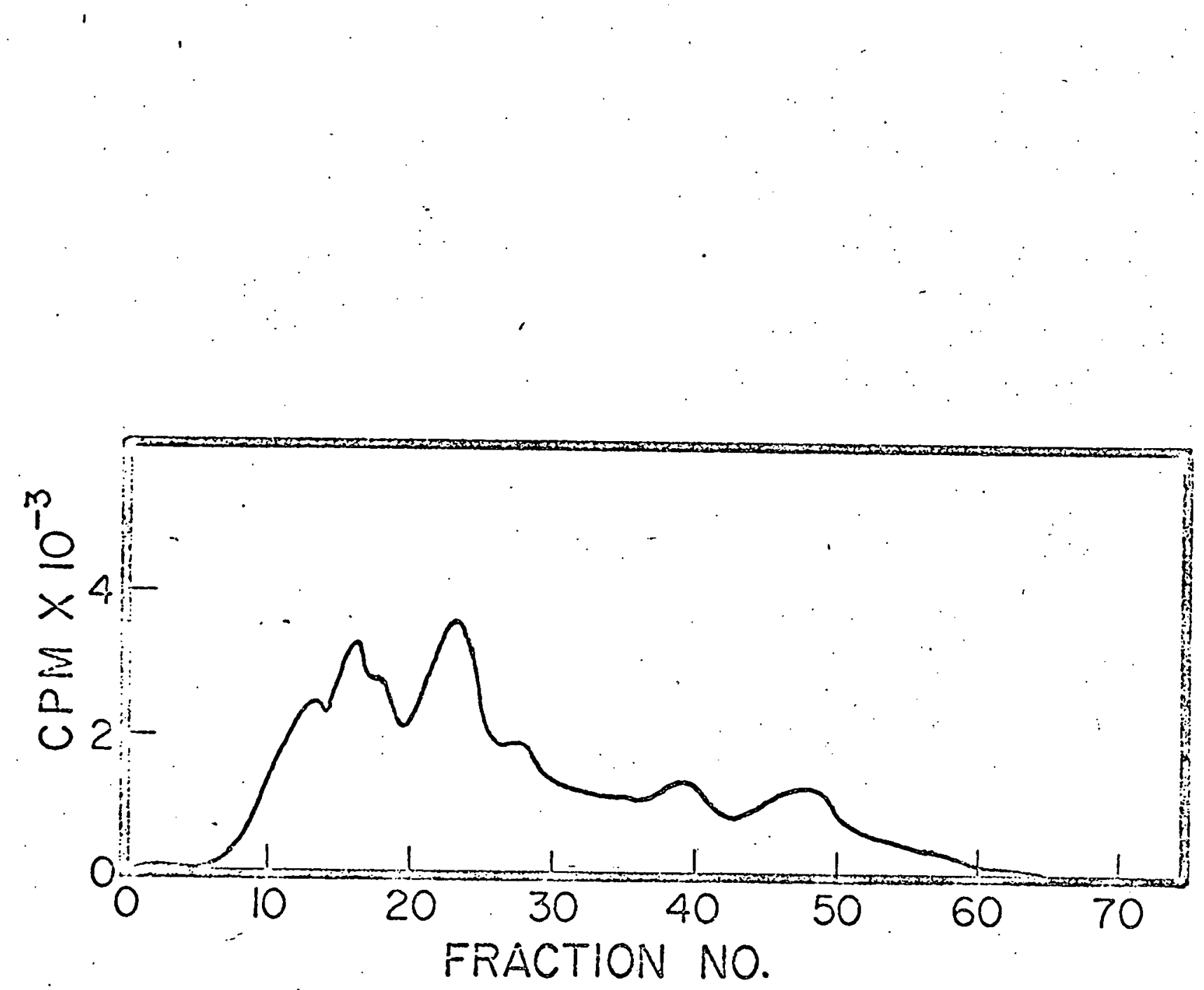




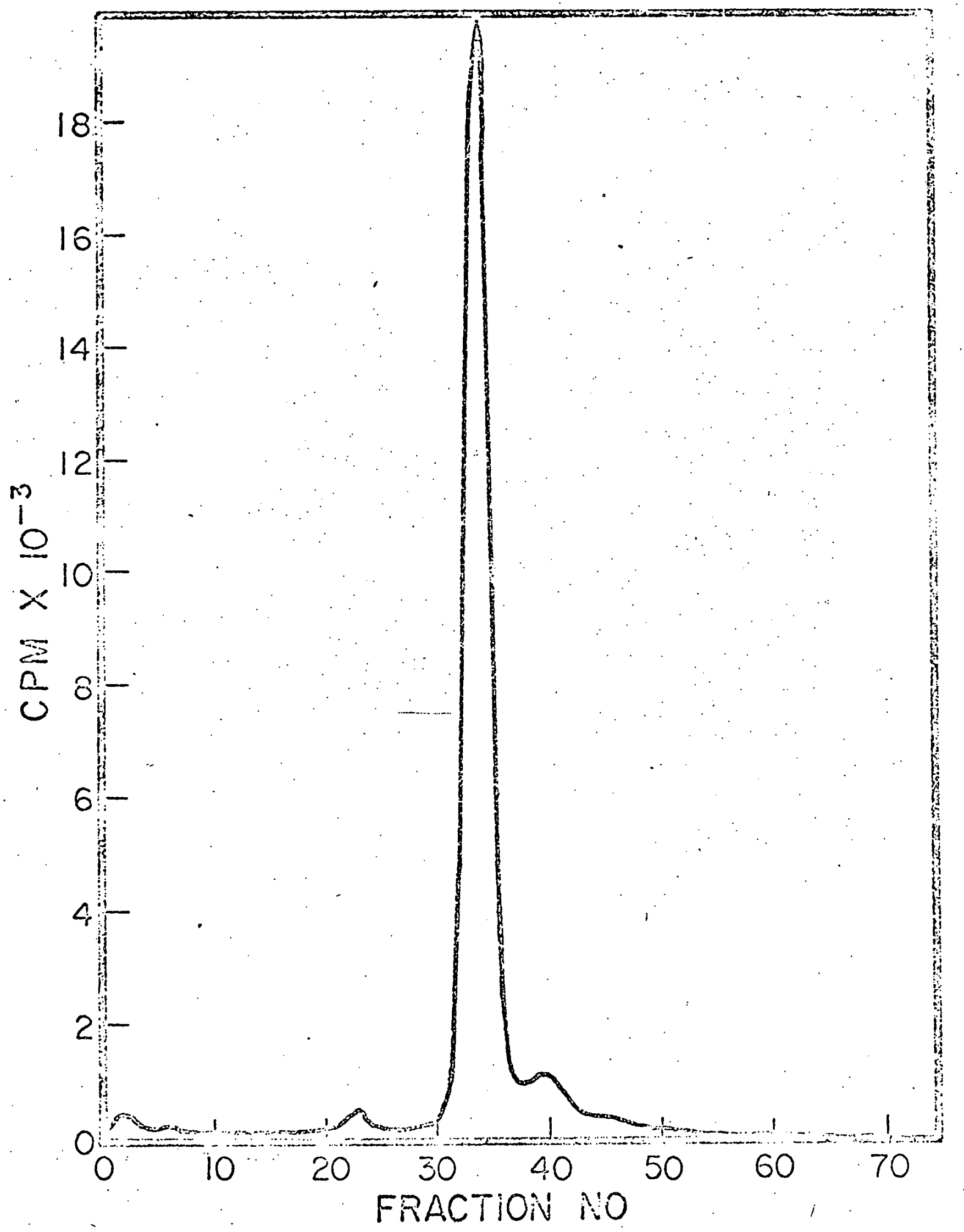

